\title{
Vas Deferens Hemorrhage
}

National Cancer Institute

\section{Source}

National Cancer Institute. Vas Deferens Hemorrhage. NCI Thesaurus. Code C78705.

Bleeding originating from the vas deferens. 